\title{
Specific Migration in Indonesia Mudik and Balik
}

\section{Lebaran}

\author{
Ketut Prasetyo \\ Universitas Negeri Surabaya \\ Surabaya, Indonesia \\ ketutprasetyo@unesa.ac.id
}

\author{
Warsono \\ Universitas Negeri Surabaya \\ Surabaya, Indonesia \\ warsono@unesa.ac.id
}

\begin{abstract}
Lebaran is a Moslem's religious ceremony in Indonesia. Usually, in lebaran, every Moslem visit their family. In Indonesia, mudik is a term to represent a migration when Moslem goes back to their village from city, while when returning from village to city is known as balik. By referring to the data obtained by Indonesia Ministry of Transportation 2016, the data of mudik and balik lebaran in 2012 to 2016 increased. In 2012, there were 22.069.278 people, whereas, 22.144.616 people in 2013, 23.088.908 people in 2014, 23.395.367 people in 2015, and 25.495.591 people in 2016. It shows us that there is a trend of increasing numbers people who did mudik and balik lebaran at $2.0 \%$. In Indonesia, the people's origin of migration mudik and balik lebaran is from some big cities, i.e. Jakarta, Surabaya, Bandung, and Medan. Uniquely, mudik-balik lebaran in Indonesia is not only for Moslem, but also for all Indonesian regardless cultural and religion backgrounds. Consequently, this condition raises some problems at preparing sufficient transportation facilities. This is also important to avoid traffic accidents as there were some traffic problems in lebaran 2016, i.e. traffic jam on Brebes High-Way in Central Java. Another impact of mudik and balik lebaran is an urbanization in some big cities in Indonesia, of which often increases annually. As an implication, people will invite their family to move to city when returning to city.
\end{abstract}

Keywords: migration, mudik, lebaran

\section{INTRODUCTION}

Lebaran is a Moslem's religious ceremony in Indonesia. Usually, in lebaran, every Moslem visit their family. In Indonesia, mudik is a term to represent a migration when Moslem goes back to their village from city, while when returning from village to city is known as balik. By referring to the data obtained by Indonesia Ministry of Transportation 2016, the data of mudik and balik lebaran in 2012 to 2016 increased. In 2012 , there were 22.069.278 people, whereas, 22.144.616 people in $2013,23.088 .908$ people in $2014,23.395 .367$ people in 2015 , and 25.495 .591 people in 2016. It shows us that there is a trend of increasing numbers people who did mudik and balik lebaran at $2.0 \%$. In Indonesia, the people's origin of migration mudik and balik lebaran is from some big cities, i.e. Jakarta, Surabaya, Bandung, and Medan. Uniquely, mudik-balik lebaran in Indonesia is not only for Moslem, but also for all Indonesian regardless cultural and religion backgrounds. Consequently, this condition raises some problems at preparing sufficient transportation facilities. This is also important to avoid traffic accidents as there were some traffic problems in lebaran 2016, i.e. traffic jam on Brebes High-Way in Central Java. Another impact of mudik and balik lebaran is an urbanization in some big cities in Indonesia, of which often increases annually. As an implication, people will invite their family to move to city when returning to city.

\section{METHOD}

This study used the obtained data from other sources/materials. The main data used in this study were collected from seconder data. Then, the data were analyzed by referring to the theory of migration, then, were confirmed to social studies, especially about geography, sociology, and economic approaches.

\section{ANALYSIS AND SPECIFIC MUDIK AND BALIK MIGRATION IN INDONESIA}

Migration is one of people movement from their origin to particular destined areas by intending to stay permanently in the new regions. Another types of movement are circulation and commuting. However, migration is the most intended migration type since it is tightly interconnected with people's significant income. Moreover, it may give them chance to give their family money too [1].

Circulation also becomes a popular migration type. It is a movement of people from a location to another with no intention to stay permanently. Those in this category only stay one up to six months or may be longer for a purposes of crop harvesting or some seasonal works. Another type is commuting. It is a daily movement between residence and work place. Circulation migration is a long established pattern of mobility within and between countries. This type of migration is mostly occurred in countries with low income.

In Indonesia, Mantra [2] studied on commuting workers in Yogyakarta City. His study resulted that commuting is characterized as follows: 1) the distance from home to work place can be reached less than an hour, 2) the transportation facility was good, and 3) the workers had strong emotional connection with their hometown. In Yogyakarta, local people call commuting as "nglaju". 
Mudik and balik lebaran are similar to circulation movement, however, a bit different at time and temporary movement. In addition, both mudik and balik lebaran movement are dominated by religious rationales. Thus, mudik and balik lebaran are indeed impermanent movement.

When we evaluate mudik and balik lebaran with Ravenstein's law of migration, there is a difference between Ravenstein's law and phenomena of mudik and balik lebaran. In Ravenstein's law, every migration flow generates a return or counter-migration, the majority of a short distance migrants and those who move longer distances tend to choose big city destinations, whereas, urban residents are often less migratory than inhabitants of rural areas, and families are less likely to make international moves than young adults. The one of popular migration theory is the one introduced by Everret S Lee. In this study, we use this migration theory proposed by Everret $\mathrm{S}$ Lee.

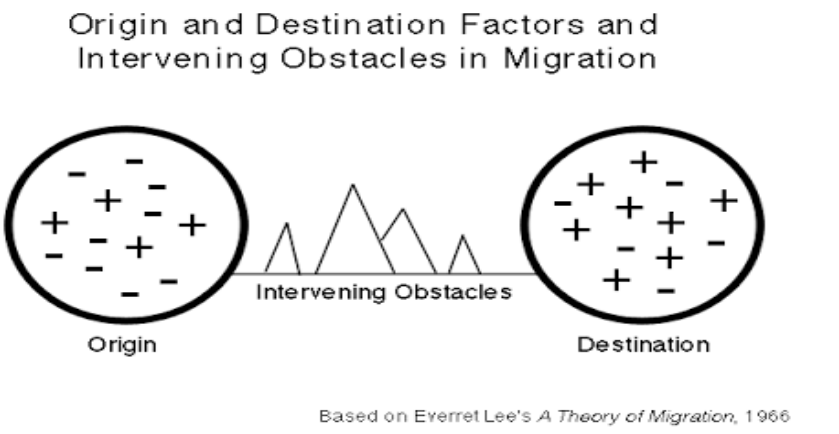

Figure 1. Migration Model of Everret Lee

When we are confirmed the phenomena of mudik and balik lebaran with pull and push theory by Lee, the origin and destination are dominated by religious persons. In Indonesia, there is a habit for young Moslem family to visit the older ones in lebaran days, or also called Idul Fitri days.

In addition, Lee's theory is only used for some moves because it has very strong religious motivation in a movement. However, some districts in Central or East Java Provinces, the young Moslem must visit the older ones in lebaran days. The varied obstacles in Lee's theory cannot be applied in mudik and balik Lebaran phenomena.

The phenomena of Mudik and balik must be well-planned. Why do we need to plan them? It is because there is an increasing number of those who did mudik-balik during 20102016 periods. Moreover, an account predicts that Indonesia's population was $240,145,657$ in 2016 , but now the population raises up to $254,000,000$ [3].

In accordance with the condition of Indonesian population, it is important to prepare transportation facilities and other supported systems for a better transportation management. Every year, since the preparation of transportation facilities especially in mudik and balik lebaran is not ready yet, numbers of traffic jams are almost happened in several places or streets. For instance, annually, one place at Northern Java Street is usually crowded during lebaran season. In 2016, the center of traffic jam is at the exit gate of Brebes High Way.

In 2016, there were 25.000 million travelers who did mudik and balik lebaran. When we analyze the data of returning to urban areas happened in 2012 to 2016 , there was an increasing number of travelers. The data below shows annual (from 2012 to 2016) counts of travelers in mudik and balik activities.
The sources of mudik are obtained from some big cities, for example, Jakarta, Bandung, and Surabaya. In accordance with the obtained data, in lebaran, the amount of population in big cities became $1 / 3$ from the normal. It means that $2 / 3$ of the population goes back to urban or their village.

Moreover, 2/3 of people in big cities mostly make the streets crowded during lebaran days. Finally, it causes traffic jams. Besides, mudik and balik lebaran also cause some accidents. Table 1 shows some accidents at mudik and balik lebaran, especially at day minus 6 (D-6) and day plus 6 (D+6).

Table 1. Traffic Accident at Mudik and Balik Lebaran (D-6 AT D+6)

\begin{tabular}{llcccc}
\hline \multirow{2}{*}{ No } & \multirow{2}{*}{ Description } & \multicolumn{2}{c}{ Years } & \multicolumn{2}{c}{ Trend } \\
\cline { 3 - 6 } & & 2015 & 2016 & Evaluat & $\%$ \\
\hline 1. & Number of accident & 2941 & 2601 & -340 & - \\
& & & & & 11,56 \\
2. Die & 635 & 483 & -152 & - \\
& & & & & 23,94 \\
3. & High accident & 1036 & 844 & -192 & - \\
& & & & & 18,53 \\
4. & Low accident & 3787 & 3464 & -323 & $-8,53$ \\
\hline
\end{tabular}

Source: Korlantas Polri

Based on above data, traffic accident was decreasing annually. Henceforth, lebaran days are moments awaited by Indonesian. They move from city to urban regions for visiting their family every year.

\section{DISCUSSION}

\section{A. Geography Approach}

Distance is not an obstacle factor, but motivation to visit his family on rural or village is the push dominant factor to mudik and balik lebaran. Times of choosing for migration or moving are almost similar. In other words, people return to village or urban areas visiting their family as similar as others. Choosing of the same time of returning to village impacts to the crowded streets or numbers of traffic accidents. The peak of choosing time to return to village or rural usually in day 3 minus lebaran day, while the peak of going back to the city is day 3 plus lebaran day. Why do they choose the similar times? Is vacancy done at the same day? This situation will be a problem in using street and transportation management. Every year, the amount of vehicles in streets always increases. Figure 2 shows the numbers of transportations available at lebaran in 2010-2016 periods. 


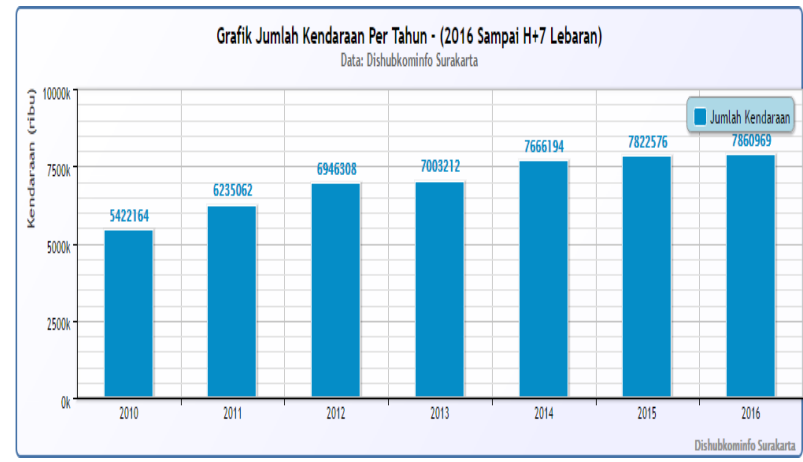

Figure 2. Numbers of Transportation at lebaran 2016 until +7 days

\section{B. Sociologal Approach}

In sociology approach, the phenomena of mudik and balik Lebaran emphasizes on studying societies, both as individual entities and as elements of a global perspective. Lebaran is a ceremonial day for Moslem in Indonesia, or so-called Idul Fitri. On the day, the Moslems do silaturohmi. In a big Moslem family, people usually meet up at their village. Traditionally, younger family members visit their older relatives. Now, the tradition of mudik and balik lebaran is not only for Moslem, but also for those non-Moslem. It is assumed that the non-Moslem want to spend the long holidays during lebaran days.

\section{Economic Approach}

Based on Economic study, the phenomena of mudik and balik lebaran is closely connected with production, distribution and consumption for materials and services. By referring to Indonesia Bank, the distribution of money at during lebaran and fasting month reached 160 trillion rupiahs. This real fact become a moment of money inflation since there are so many economic activities. Among 125 population who did mudik and balik were spending moneys around 25 trillion rupiahs or equal with 12 billion USD. They used the money for transportation, accommodation, and hand-up. Another use is for private matters such meals and other needs. In fact, by referring to Trisno Yulianto [4], some people change the old money with the new ones once they arrived at their destined village.

\section{CONCLUSION}

Almost similar to migration circular, mudik and balik lebaran are dominated by religious matters or reasons. Of cources, the phenomena of mudik and balik lebaran are mirrored a specific migration theory.

\section{REFERENCES}

[1] J Lestryowati, “Jumlah Uang Beredar. Inflasi, dan Fenomen Mudik”, Yogyakarta : BDK, 2014.

[2] I B Mantra, "Migrasi Sirkuler," Yogyakarta : Obor, 1986.

[3] BPS, Bappenas, UNFPA, "Population Prediction Living in Urban”, 2014.

[4] T Yulianto, "Desa dan Ekonomi Lebaran (Rural and Economic Lebaran)", Jogyakarta: Obor, 2016. 